\title{
Fruit Production of Berberis buxifolia Lam. in Tierra del Fuego
}

\author{
M.E. Arena and G. Vater \\ Centro Austral de Investigaciones Científicas (CONICET), C.c. 92 (9410) \\ Ushuaia, Tierra del Fuego, Argentina
}

\author{
P. Peri \\ UNPA, Convenio UNPA-INTA-CAP, C.c. 332 (9400) Río Gallegos, Santa \\ Cruz, Argentina
}

Additional index words. Patagonia, barberry, phenology, fruiting

\begin{abstract}
The aim of this work was to study the phenology and fruiting characteristics of B. buxifolia Lam. at Tierra del Fuego, Argentina. One-year-old shoots had significantly more and heavier fruit than older ones. The orientation, height position, and age of shoots significantly affected the shrub productivity. The highest relative number of fruiting shoots, fruit number and fruit weight were found on the northern side of shrub, followed by eastern, western and southern orientations. The relative number of fruiting shoots, fruit number and fruit weight were higher in the upper half of the plant. One-year-old fruiting shoots were significantly higher than 2- and 3-year-old shoots. Likewise, the relative fruit number and fruit weight were significantly higher on 1-year-old than older shoots.
\end{abstract}

Over the last few years, an increasing interest has been shown in intensive agriculture in Patagonia (Arena and Martínez Pastur, 1995a; INTA EEA Santa Cruz, 1996; Martínez et al., 1995; Riádigos and Martínez, 1994). This is due mainly to the possibility of out-of-season production for Northern Hemisphere markets. Also, a wide diversity of soils and climates are represented in Patagonia that could be used to extend the production season.

Berberis is a native shrub represented by 16 species in Patagonia (Bottini et al., 1993; Orsi, 1984). Berberis buxifolia Lam., commonly named "calafate," has the largest distribution, from Neuquén ( $\left.37^{\circ} \mathrm{SL}\right)$ to

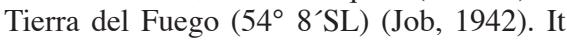
is an evergreen, spiny and erect shrub up to 4 $\mathrm{m}$ high often growing in coastal scrub, forest margins and clearings, moist areas in the grass steppe, and along streams and rivers (Moore, 1983). Berberis buxifolia can be propagated from seeds (Arena and Martínez Pastur, 1994), rhizomes (Arena and Martínez Pastur, 1995b; Arena et al., 1998), and through in vitro methods (Arena et al., 2000). When plants are obtained from rhizomes, they acquire the adult characteristics at the third growing season and flower. Commercial orchards of B. buxifolia are being planned, because its black-blue fruits can be eaten fresh or in marmalades and jams (Bottini et al., 1993; Orsi, 1984), and they are an important source of alkaloids as berberines and anthocyanins (with medicinal and tinctotial application) (Fajardo Morales, 1987; Fajardo Morales et al., 1986; Pomilo, 1973; Shaffer, 1985). Berberis heterophylla plants have been used to prevent desertification and for natural windbreaks in Chilean Patagonia. In addition, due to the adult plant structure of Berberis as the presence of spines, these shrubs can not be easy eaten by the animals and protect other

Received for publication 5 Mar. 2002. Accepted for publication 23 Aug. 2002. plant species growing near them (Bottini et al., 1993). Also, the high foliage density of the shrubs reduce the wind effect and this fact allow to reduce the mortality of the sheep (Bustos, 1995).

At present there are only a few reports on Berberis fruit production (Allen and Wilson, 1992; Arena et al., 1999, 2001; Peri et al., 1998a). The main objective of this work was to study the phenology and fruiting characteristics of B. buxifolia Lam. at Tierra del Fuego, Argentina, as a first step toward its domestication.

\section{Materials and Methods}

Geographic situation and site description. The study area is located near Ushuaia

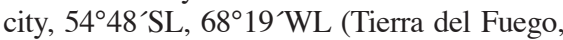
Argentina). Climatic data on maximal, minimal, and mean daily temperatures $\left({ }^{\circ} \mathrm{C}\right)$; mean ambient relative humidity; and accumulated precipitation (mm) were recorded by the Meteorological Station at Centro Austral de Investigaciones Científicas from October to April for the 1996/97 to $1998 / 99$ seasons. Data on ultraviolet and visible radiation $(290-600 \mathrm{~nm})\left(\mathrm{J} \cdot \mathrm{cm}^{-2}\right)$ and solar elevation angle $\left(^{\circ}\right)$ were also taken over the same period at the Laboratorio de UV y Ozono del Centro Austral de Investigaciones Científicas, using the spectroradiometer that belongs to the NSF UV Radiation Monitoring Network. The maximum solar elevation angle was $58.28^{\circ}$ on $21 \mathrm{Dec}$. and the minimum was $11.50^{\circ}$ on 21 June.

Soil samples were collected in the spring of 1997 from two horizons (0-0.14 and 0.14-0.29 $\mathrm{m}$ ) and were analyzed at the Laboratorio de Suelos del Consejo Agrario Provincial (Santa Cruz) "Agr, Horst Thierauf." The soil had an acceptable C:N ratio, was not saline but it was $\mathrm{K}$ deficient (Table 1).

Plant material description. Ten B. buxifolia plants growing naturally in association with
Chiliotrichium diffusum, were selected that were similar in size and age. The mean height was $0.84 \pm 0.15 \mathrm{~m}$, and the mean diameters were $2.18 \pm 0.40 \times 1.70 \pm 0.46 \mathrm{~m}$. The plants were estimated to be $8-10$ years old, by counting the number of growth rings in main stem cross sections. However, stems with different ages may be found in the same plant, since they propagate naturally by rhizomes (Arena and Martínez Pastur, 1995b; Arena et al., 1998).

Phenology. The following phenological phases were observed from Sept. to Mar. 1996/97 and 1997/98: new leaf emergence, appearance of unopened flower, full flower, fruit set, and ripening period. The reproductive performance was also studied in shoots of different age on the selected plants. The numbers of unopened flowers, opened flowers, fruit that had set and ripened fruits per shoot were recorded at $\approx 7$ - to 10 -d intervals from Oct. 1997 to the end of Jan. 1998.

Fruit production. Fruit production was measured for shoots aged 1, 2, and 3 or more year old in four quadrants of each shrub (North, East, South, and West), at two height positions (upper and lower half). The number and weight of fruits were analyzed over two growing seasons (Feb. 1998 and 1999). In addition, the relationship between the number of shoots grown at the end of the growing season in 1997 and the number of 1-year-old fruiting shoots during the 1998 summer was evaluated. Results were analyzed by Fisher and Tukey tests, with a significance level of $P<0.05$.

\section{Results and Discussion}

Phenology. New leaf emergence and full flower occurred in early and mid-spring, respectively (Table 2). Fruit ripening continued for 15 to $20 \mathrm{~d}$ in January and early February. All the phenological phases occurred $\approx 20 \mathrm{~d}$ later in the 1997/98 season than in 1996/97 season, even though the mean temperatures for the $1997 / 98$ season were only $0.33{ }^{\circ} \mathrm{C}$ higher than in the 1996/97 season. However, the mean and maximum temperatures from October to January were $0.80{ }^{\circ} \mathrm{C}$ and $2.12{ }^{\circ} \mathrm{C}$ higher in $1996 / 1997$ than in $1997 / 1998$ season, and the precipitation in 1996/1997 was less than half than in the 1997/1998 season. Higher temperatures and lower precipitation from October to January could advance the phenological phases, explaining the differences between the 1996/1997 and 1997/1998 seasons.

An average of 15 unopened flowers was formed per shoot and $89 \%$ of them ultimately opened. However, only $29 \%$ of the unopened flowers became fruits and only $16 \%$ of these ripened. There were not significant differences in the reproductive performance among shoots of different ages (data not shown). The reasons why so few flowers produced ripened fruits was not determined, but could be caused by an abscission process related to fruit load or by insect attack. In contrast, Allen and Wilson (1992) reported that for naturalized plants of Berberis darwinii $43.5 \%$ to $54.8 \%$ of mature flowers produced ripe fruits, a value much higher than was observed in this study. 
Table 1. Climatic data on maximal (Max), minimal (Min), and mean daily temperatures $\left({ }^{\circ} \mathrm{C}\right)$; mean ambient relative humidity $(\mathrm{RH})$; accumulated precipitation $(\mathrm{mm})(\mathrm{PR})$; ultraviolet and visible radiation $\left(\mathrm{J} \cdot \mathrm{cm}^{-2}\right)$ (RAD) from October to April for 1996/97 to 1998/99 seasons at Ushuaia, Argentina. Soil data are also presented including texture, $\mathrm{pH}$, concentration $(\%)$ of organic carbon $(\mathrm{C})$, nitrogen $(\mathrm{N})$, potassium $(\mathrm{K})$, phosphorus $(\mathrm{P}), \mathrm{C}: \mathrm{N}$ ratio and resistance (ohm.cm).

\begin{tabular}{|c|c|c|c|c|c|c|c|c|}
\hline Climatic data & Max & Min & & & RH & \multicolumn{2}{|c|}{ PR } & RAD \\
\hline \multicolumn{9}{|c|}{ Seasons } \\
\hline $1996 / 97$ & 12.44 & 4.01 & & & 72.06 & \multicolumn{2}{|c|}{289.40} & 15750.41 \\
\hline $1997 / 98$ & 12.07 & 5.42 & & & 73.78 & \multicolumn{2}{|c|}{341.90} & 17082.84 \\
\hline $1998 / 99$ & 12.15 & 4.91 & & & 70.51 & \multicolumn{2}{|c|}{320.70} & 16549.26 \\
\hline Soil data & Texture & $\mathrm{pH}$ & $\mathrm{C}$ & $\mathrm{N}$ & K & $\mathrm{P}$ & $\mathrm{C}: \mathrm{N}$ & Resistance \\
\hline \multicolumn{9}{|c|}{ Horizons } \\
\hline Superficial & Organic & 4.3 & 7.93 & 0.58 & 0.20 & 8.00 & 13.53 & 7000 \\
\hline Deep & Silt-sandy & 4.2 & 2.94 & 0.20 & 0.10 & Traces & 14.26 & 20000 \\
\hline
\end{tabular}

Table 2. Dates of the various phenological phases of B. buxifolia plants growing naturally near Ushuaia city, Tierra del Fuego, from Sept. to Mar. 1996/97 and 1997/98 seasons.

\begin{tabular}{lcccccc}
\hline & New leaf & Appearance of & Full & Fruit & \multicolumn{2}{c}{ Ripening period } \\
\cline { 6 - 7 } Period & emergence & unopened flower & flower & set & Beginning & End \\
\hline $1996 / 97$ & 22 Sept. & 7 Oct. & 22 Oct. & 13 Nov. & 8 Jan. & 30 Jan. \\
$1997 / 98$ & 13 Oct. & 27 Oct. & 10 Nov. & 2 Dec. & 19 Jan. & 4 Feb. \\
\hline
\end{tabular}

Table 3. Multifactorial analysis of variance for fruit number (FN) and weight $(\mathrm{FW})(\mathrm{g})$ of fruits harvested per shoot and mean fruit weight $(\mathrm{MFW})(\mathrm{g})$ at different shrub orientations, height position, and shoot age of B. buxifolia plants growing naturally near Ushuaia city, Tierra del Fuego.

\begin{tabular}{lccc}
\hline Factor & FN & FW & MFW \\
\hline & \multicolumn{4}{c}{ Shrub orientation } \\
North & 1.46 & 0.37 & 0.24 \\
East & 1.63 & 0.46 & 0.27 \\
South & 1.46 & 0.40 & 0.26 \\
West & 1.54 & 0.41 & 0.26 \\
& \multicolumn{4}{c}{ Height position } \\
Upper & 1.56 & 0.43 & 0.26 \\
Lower & 1.48 & 0.39 & 0.25 \\
& & Shoot age & \\
1 & $1.85 \mathrm{a}^{\mathrm{z}}$ & $0.51 \mathrm{a}$ & 0.27 \\
2 & $1.55 \mathrm{~b}$ & $0.44 \mathrm{ab}$ & 0.27 \\
3 & $1.17 \mathrm{c}$ & $0.28 \mathrm{~b}$ & 0.23 \\
& \multicolumn{4}{c}{ Level of significance of main effects } \\
Shrub orientation & 0.6316 & 0.8519 & 0.9102 \\
Height position & 0.4948 & 0.6173 & 0.7421 \\
Shoot age & 0.0000 & 0.0461 & 0.6641 \\
Interaction & 0.9606 & 0.9929 & 0.9951 \\
\hline
\end{tabular}

${ }^{\mathrm{z}}$ Means followed by different letters for each factor and in each column mean significant differences through Tukey test at $P<0.05$.

ynteraction is calculated among shrub orientation, height position, and shoot age.

Fruitproduction.Age significantly affected the number and weight of fruits harvested per shoot (Table 3). One-year-old shoots had significantly more and heavier fruits than the older shoots. In the east orientation, the number and weight of fruits harvested per shoot and the mean fruit weight were also higher compared to other orientations, although there were not significant differences. Fruit yield in the upper half of the plants was higher respect to the lower half, but again these differences were not significant.

The orientation, height position, and age of shoots significantly affected the plant productivity (Table 4). The highest relative numbers of fruiting shoots, fruit numbers, and fruit weights were found on the northern side of bushes, followed by the eastern, western, and southern orientations. The highest relative numbers of fruiting shoots, fruit numbers, weight) on the northern section in respect to the other orientations was due to a higher number of shoots being formed on the north, but not to a higher fruit yield per shoot. These results are consistent with those found for B. heterophylla, whose fruit yield was maximum on northeast and northwest orientations (Peri et al., 1998a), although fruit yield per shoot was maximum in those orientations (Arena et al., 2001). The higher values found on the northern side could be due to a longer exposure to the sun and consequently too high light intensity, and to a less exposure to the predominant winds from the south-southwest. The positive effect of windbreaks for increasing fruiting and yield was reported by Peri et al. (1998b) on strawberry plants at Santa Cruz (Argentina).

The highest relative fruit yield (number and weight) in the upper half of the plant, was also due to a higher shoot formation, but not to a higher fruit yield per shoot. Similarly, the fruit yield of $B$. heterophylla was maximum in the upper half of the plants (Peri et al., 1998a), although fruit yield per shoot was maximum in this part of the plant (Arena et al., 2001). However, the height of the plant did not affect the reproductive performance in $B$. darwini plants grown at the forest edge (Allen and Wilson, 1992). The highest shoot formation and fruit yield in the upper half could be explained by an increment in light intensity (Vozmediano, 1982). Shading reduced fruit set and yield in Ericaceae species (Patten and Wang, 1994; Roper et al., 1995) and in Malus domestica (Doud and Ferree, 1980). This highlights the importance of pruning, to enhance light penetration into the shrub canopy.

The highest relative fruit yield of 1-yearold shoots was due to their being more fruitful than the other aged shoots, and their having a higher number and weight of fruits. This is in agreement with the results found for $B$. heterophylla (Arena et al., 2001; Peri et al., 1998a). The percentage of 1-year-old shoots was similar in the upper half of the plant with respect to the lower part (data not shown). In general, shoots have different vigor depending on their position, direction of growth, and age (Calderón Alcaráz, 1993). These differences in vigor can be explained by the carbon/nitrogen ratio and by differences in auxins concentration. Thus, 1-year-old shoots may have a better physiological equilibrium (in terms of vigor) compared with the older shoots and are more likely to form fruits. Our results showed that fruiting shoots older than 2 years represented $\approx 20 \%$ of the total fruiting shoots, producing only $14 \%$ of the total bush fruit yield. This highlights the necessity for pruning out older shoots, leaving only younger shoots with a greater capacity for producing fruits.

Only $8 \%$ of the shoots present at the end of the growing season in 1997 formed fruits during Summer 1998. These values ranged greatly from $3.5 \%$ to $19.0 \%$ among plants, with a maximum at the northern $(11.6 \%)$ and a minimum at the western and southern orientations $(6.3 \%)$. These results confirm the effect of orientation on yield and could indicate that the physiological equilibrium among these shrubs and across the shrub would be different. 
Table 4. Analysis of variance for the relative (percentage with respect to the total of the plant) number of fruiting shoots (NFS), fruit number (FN), and fruit weight (FW) at different shrub orientations, height position, and shoot age of B. buxifolia plants growing naturally near Ushuaia city, Tierra del Fuego. The variables were analyzed considering the studied factors individually.

\begin{tabular}{|c|c|c|c|}
\hline Factor & NFS & FN & FW \\
\hline & \multicolumn{3}{|c|}{ Shrub orientation } \\
\hline North & $35.12 \mathrm{a}^{2}$ & $38.15 \mathrm{a}$ & $37.05 \mathrm{a}$ \\
\hline East & $26.11 \mathrm{ab}$ & $22.49 \mathrm{ab}$ & $24.71 \mathrm{ab}$ \\
\hline South & $16.39 \mathrm{~b}$ & $17.81 \mathrm{~b}$ & $17.91 \mathrm{~b}$ \\
\hline \multirow[t]{2}{*}{ West } & $22.37 \mathrm{ab}$ & $21.52 \mathrm{ab}$ & $20.31 \mathrm{ab}$ \\
\hline & \multicolumn{3}{|c|}{ Height position } \\
\hline Upper & $85.64 \mathrm{a}$ & $86.98 \mathrm{a}$ & $87.66 \mathrm{a}$ \\
\hline \multirow[t]{2}{*}{ Lower } & $14.35 \mathrm{~b}$ & $13.01 \mathrm{~b}$ & $12.33 \mathrm{~b}$ \\
\hline & \multicolumn{3}{|c|}{ Shoot age } \\
\hline 1 & $61.59 \mathrm{a}$ & $67.06 \mathrm{a}$ & $67.96 \mathrm{a}$ \\
\hline 2 & $18.84 \mathrm{~b}$ & $17.10 \mathrm{~b}$ & $17.68 \mathrm{~b}$ \\
\hline \multirow[t]{2}{*}{3} & $19.56 \mathrm{~b}$ & $15.83 \mathrm{~b}$ & $14.35 \mathrm{~b}$ \\
\hline & \multicolumn{3}{|c|}{ Level of significance of main effects } \\
\hline Shrub orientation & 0.0357 & 0.0140 & 0.0349 \\
\hline Height position & 0.0000 & 0.0000 & 0.0000 \\
\hline Shoot age & 0.0000 & 0.0000 & 0.0000 \\
\hline
\end{tabular}

${ }^{2}$ Means followed by different letters for each factor and in each column mean significant differences through Tukey test at $P<0.05$.

\section{Literature Cited}

Allen, R.B. and J.B. Wilson. 1992. Fruit and seed production in Berberis darwinii Hook., a shrub recently naturalised in New Zealand. N.Z. J. Bot. 30:45-55.

Arena, M.E. and G. Martínez Pastur. 1994. Seed propagation of Berberis buxifolia Lam. Phyton 56(XII):59-63.

Arena, M.E. and G. Martínez Pastur. 1995a. In vitro propagation of Ribes magellanicum Poiret. Scientia Hort. 62:139-144.

Arena, M.E. and G. Martínez Pastur. 1995b. Propagación de frutales menores nativos de los Bosques Andino-Patagónicos: El calafate. Presencia 10(37):5-7.

Arena, M.E., G. Martínez Pastur, and G. Vater. 2000. In vitro propagation of Berberis buxifolia Lam. Biocell 24(1):73-80.

Arena, M.E., G. Vater, and P. Peri. 1998. Propagación por rizomas de los Berberis de la Patagonia Austral. Proc. IX Congreso Latinoamericano de Horticultura, XLIX Congreso Agronómico de Chile: 96. Santiago, Chile.
Arena, M.E., G. Vater, and P. Peri. 1999. Análisis de la producción de frutos en Berberis buxifolia Lam. "calafate" de la Patagonia Austral. Proc. XIX Reunión Argentina de Ecología: Sección Ecofisiología 145. Tucumán, Argentina.

Arena, M.E., P. Peri, and G. Vater. 2001. Producción de frutos y crecimiento de Berberis heterophylla Juss. en dos sitios de la Patagonia austral. Revista de Investigación Agraria, Serie: Producción y Protección Vegetales 16(1):49-57.

Bottini, M.C., C. Bustos, and D. Bran. 1993. Arbustos de la Patagonia, Calafates y Michay. Presencia 8(30):5-9.

Bustos, C. 1995. Uso de cortinas de arbustos para atenuar la mortandad perinatal de los corderos. Presencia 10 (35):5-8.

Calderón Alcaraz, E. 1993. La poda de los árboles frutales. De Limusa. México.

Doud D.S. and D.C. Ferree. 1980. Influence of altered light levels on growth and fruiting of mature "Delicious" apple trees. J. Amer. Soc. Hort. Sci. 105:325-328.

Fajardo Morales, V., F. Podestá, and A. Urzúa. 1986.
Reseña de los alcaloides encontrados en el género Berberis de Chile. Revista Latinoamericana de Química 16:141-156.

Fajardo Morales, V. 1987. Estudio químico de las especies chilenas del género Berberis. Revista Latinoamericana de Química 18:46-50.

INTA EEA Santa Cruz. 1996. Programa para el desarrollo de la Agricultura en la Provincia de Santa Cruz. Propuesta 1996.

Job, M.M. 1942. Los Berberis de la región del Nahuel-Huapi. Rev Museo de La Plata (Sección Botánica). 5:21-72.

Martínez,E.,A. De Michelis, and E. Riádigos. 1995. En la variedad está el gusto... y el negocio. Campo y Tecnología 21:39-42.

Moore, D.M. 1983. Flora of Tierra del Fuego. Anthony Nelson \& Missouri Botanical Garden.

Orsi, M.C. 1984. Berberidaceae, p. 325-348. In: Flora Patagónica IV, Tomo VIII. Ed INTA. Buenos Aires, Argentina.

Patten, K.D. and J. Wang. 1994. Cranberry yield and fruit quality reduction caused by weed competition. HortScience 29:199-201.

Peri, P., G. Vater, and M.E. Arena. 1998a. Producción de frutos en Berberis heterophylla "calafate" de la Patagonia Austral. Proc. IX Congreso Latinoamericano de Horticultura, XLIX Congreso Agronómico de Chile: 46. Santiago, Chile.

Peri, P., E. Cittadini, H. Espina, and G. Romano. 1998b. Incidencia del efecto protector de cortinas forestales en la producción de frutilla variedad Fern en Santa Cruz, Argentina. Proc. Primer Congreso Latinoamericano de IUFRO. Tema 2(13): Sistemas Integrados de Producción y Desarrollo Rural. Valdivia, Chile.

Pomilo,A.B. 1973. Anthocyanins in fruits of Berberis buxifolia. Phytochemistry 12:218-220.

Riádigos, E. and E. Martínez. 1994. Producción de frambuesas en los valles patagónicos. Presencia 9(32):20-21.

Roper T.R, J. Klueh, and M. Hagidimitriou. 1995. Shading timing and intensity influences fruit set and yield in cranberry. HortScience 30 : 525-527.

Shaffer, J.E. 1985. Inotropic and chronotropic activity of Berberine on Isolated Guinea Pig Atria. J. Cardiovascular Pharmacol. 7:307-315.

Vozmediano, J. 1982. Fruticultura: Fisiología, ecología del árbol frutal y tecnología. Ed Servicio de Publicación Agraria, España. 